\title{
Applying Grey Relational Analysis to Evaluate Internal Marketing Practice: A Cross-Cultural Case Study in Taiwan and Mainland China Hotels
}

\author{
Yu-Ting Huang \\ Department of Tourism, Shih Hsin University \\ Email:ythuang@mail.shu.edu.tw \\ Tzong-Ru (Jiun-Shen) Lee \\ Department of Marketing, National Chung Hsing University \\ Email: trlee@dragon.nchu.edu.tw \\ Yi-Jyun Jiang \\ Department of Applied Economics, National Chung Hsing University \\ Email: ucashieve@gmail.com
}

\begin{abstract}
The need for real enhancement of capabilities of an organization to provide various valuable services for customers, as fundamental to competitive advantage, has become a significant issue. This paper aims to consider employee satisfaction by collecting in Taiwan and mainland China hotel industry. It is conducted by referring to the grey relative analysis method to examine what demands employee expects and requires. The findings indicated that employees in both countries have similar requirements for internal marketing regarding personal demographics, although they are under different growing backgrounds and environments. The findings also have implications for the manager in the services organization.
\end{abstract}

Keywords: Internal marketing practice, Employee satisfaction, Cultural issues, Grey relative analysis

\section{INTRODUCTION}

The hospitality industry, especially the lodging industry, is facing a highly competitive environment. The formulation of a marketing strategy, optimising service quality, and consolidating business operations has become essential not only for 
profitability but also for organizational survival (Hwang \& Chang, 2003), which all depend upon the management efficiency. From the 1970s, the research (e.g., Teague \& Eilon, 1973) has already indicated that the issue of efficiency may need to be addressed and examined. Moreover, the level of competition in an accommodation market, due to the oligopolistic market, demands efficiency (Barros, 2004; Phillips, 1999). From the 1970s, the research (e.g., Teague \& Eilon, 1973) has already indicated that the issue of efficiency may need to be addressed and measured. Increasingly, it has been recognized that companies face two kinds of markets and customers: internal and external (e.g., Morgan \& Piercy, 1992). This view, which has been successfully adopted managing the implementation of organizational strategies (Kim, Song, \& Lee, 2016), has significant implications for the issues of customer satisfaction both in analyzing the barriers they may face and in designing effective implementation strategies.

The need for real enhancement of capabilities of an organization to provide various valuable services for customers, as fundamental to competitive strategy and advantage, has become a significant issue in the management literature (Varey, 1995). To perform successfully, tourism and hospitality organizations must apply external marketing in addition to internal and interactive marketing (Flipo,1986; Piercy \& Morgan, 1995). Hence, a conceptual model of internal marketing is employed. Internal marketing is one of the most significant factors which may utilize the employees' skills, attitudes, and behavior to deliver service as employees will eventually be responsible for providing services or even better quality, which is expected by the customer. On the other hand, a human resource manager may face the risk that well-trained employees will become an attractive potential workforce for other competitors. Thus, decreasing employee turnover intention of new employees is a significant organizational issue that merits thorough exploration.

To our knowledge, very few turnover determinant studies related to hotel employees (Joung, Goh, Huffman, Yuan, \& Surles, 2015), which is not surprising since there are severe data limitations in such studies. The main reason is that information on job fluctuations ideally requires examining employees who have turnover intention. In reality, an organizational-wide survey may have difficulty to target the right employees who have the turnover intention and to question them turnover determinants. Fortunately, turnover intentions and those employees' satisfaction were strongly correlated (Kim, et al., 2016). Indeed, as has often been pointed out, due to direct involvement of employees in the system of service delivery, designing strategies to satisfy their needs, arranging programs to maintain their skills, commutating with them to understand their thinking, and identifying their roles to assist their performance affect employee attitude and satisfaction and reduce employee turnover.

This research aims to consider employee satisfaction from data collected in Taiwan 
and mainland China that targets Taiwanese and Chinese who work in the hotel industry. This study aims to understand what demands and requirements of internal marketing employees concern to improve their satisfaction. The unique contribution expected from this study is that, to date, no study has empirically been able to understand the inherent needs of Taiwanese and Chinese hotel industry marketing employees. Based on the similarity between the two cultures, we can further explore cultural issues that need attention and related employee satisfaction. Finally, the specific objectives of this article are to look at the implementation problem as an internal marketing issue, where an employee satisfaction strategy needs to be positioned and marketed positively. If we are serious about the implementation of employee satisfaction management - this brings together the employee satisfaction issue, barriers in the internal market, and strategy in the external market, as a framework for management action.

\section{LITERATURE REVIEW}

Internal marketing was originally appeared as a marketing approach to service management to improve further external marketing concepts such as satisfaction in the 1970s. The internal marketing perspective holds that, by treating both front-line and back-office employees with the same total dedication to satisfy their demands, the organization can inspire and encourage employees to do a good quality job and deliver exceptional customer service. Therefore, it is necessary that internal marketing becomes integrated into the overall marketing strategy (Vella et al. 2009).

External marketing underlines on customers, partners and the society as significant, the central core as the employees, so the internal marketing has been defined by several academics as Gronroos (1978); Vella et al. (2009); Huang \& Rundle-Thiele (2015) defined it as "employees as internal cutometers," "as satisfying the internal cutometers' needs by offering supports to increase their satisfaction." Old views of internal marketing need to be expanded to encompass a far broader range of internal marketing states and qualities to benefit both employees and marketing managers. External relationships can useful as internal relationships work well, and internal marketing contributes to success in external markets (Ballantyne, 2000; Gronroos, 2000; Huang, Rundle-Thiele, \& Chen, 2018). Therefore, following that, the employee needs are the priority before those of the customer.

Internal marketing was initially proposed as a uni-dimensional construct. Nowadays, a common theme among these studies is the view that internal marketing consists of several different dimensions (e.g., Tsai \& Tang, 2008; Huang \& RundleThiele, 2015). The target audience of internal communication is employees (Welch \& Jackson, 2007). Several authors have indicated that managers require strong communication to deliver the organization's vision (Bearden \& Netemeyer 1999; Tsai 
\& Tang 2008). Moreover, excellent communication can assist teams to work better and improve their relationships (Peltier et al. 2006; Quester, \& Kelly, 1999; RobertsLombard, 2010). Many organizations recognize the importance of training and increasing knowledge in their employees (Bearden \& Netemeyer 1999; Tsai \& Tang 2008). Finally, internal market research can assist the manager to comprehend employee needs and demands (Chang \& Chang 2008). Nart, et al. (2019) also indicated that internal market research could provide suggestions and feedback for better service delivery process in hotels. Based on reviewing the literature, this study planned to take a deep insight into a set of factors that seen core stones in creating and developing internal marketing, which is: internal communication and training and internal market research. The purpose of this study is to explore what are employee needs and demands to deepen our understanding of internal marketing.

Lin and Lin (2010) recently undertook a review of internal marketing in the tourism context, while Huang et al. (2010) undertook a more general review of internal marketing. The complex nature of the hospitality industry different from other industries, which causes challenges about the management of employees (Tag-Eldeen \& El-Said, 2011). Internal marketing has been seen as a means of effectively managing employees for enhanced productivity (Chang \& Chang, 2008). Lo et al. (2010), for instance, proposed that hotel managers must first concern the needs of employees as a measure to building good relations with customers. Further, Huang's (2019) review study indicated that the tourism and hospitality industry was the most measured in the internal marketing field (i.e., only for English articles). However, their reviews stated that its understanding of internal marketing is European (Western) and focused on hotels. Therefore, the results of this internal marketing study are not fully applicable to the East and the broader tourism and hospitality contexts. When internal marketing has been addressed in the East (Huang \& Chi 2004; Kale 2007), academics and practitioners have not focused on cultural issues. The limited focus on cultural issues to date suggests there is a need for further research in this area. Based on the previous discussion, the second aim of this research is to identify cultural issues that are likely to be barriers to internal marketing.

A review of the literature was undertaken to identify cultural issues that may be likely to impact internal marketing and employee satisfaction.

\section{Employee Satisfaction}

Internal marketing has been used to help leverage more job satisfaction in order to motivate the workforce and optimize service quality. Similarly, Lassk, Norman, and Goolsby (2004) concluded that employee performance is essential to customer satisfaction, which, in turn, creates customer loyalty. Among the factors that affect the 
quality of services delivered to customers are employees. Employee work behaviors and performances are crucial; to the success of most organizations and must, therefore, be evaluated. Furthermore, internal marketing can assist in satisfying employees' needs. The hotel labor market has a dual face; on the one hand, it is difficult to attract suitable labor, and on the other, it has relatively high levels of turnover, representing a significant loss of investment in human capital, training, and quality. Employee turnover represents a challenge for contemporary HRM strategies and practices as there is no standard reason for leaving the existing workplace (Ongori, 2007). Therefore, employee retention has emerged as a significant area of study. Not surprisingly, the "employees as customers" philosophy (Berry, et al., 1976) underpins many internal marketing research studies as the increased awareness of employees. From the starting point, the focus in internal marketing research has shifted from an external orientation to an internal orientation with numerous papers focussing on employee satisfaction rather than customer satisfaction (see Bruhn \& Georgi, 2000) Moreover, organizations pay much attention to employees in addition to customers to be successful. Indeed, as has often been pointed out, the internal marketing perspective holds that the organisation can inspire and encourage employees to do a good quality job and deliver exceptional customer service (Bowers \& Martin, 2007; Göunaris, 2008).

\section{Culture}

Internal marketing success is based on the employee's understanding and internalization, which is affected by how individuals comprehend things. Individual comprehension is affected by the environment in which people are in. From the perspective of employing people from a culturally diverse background, levels of comprehension for an internal marketing program may vary widely (Huang \& RundleThiele, 2014). This review next considers how internal marketing success may be further enhanced by consideration of cultural issues.

An understanding of cross-cultural diversity is critical to the development of international business management. Differences in national cultures call for differences in management practices. The current kind of cultural issue drive toward globalization makes it harder. An example is that MOS Burger is the same around worldwide, although most branches are located in the East, such as Taiwan and Singapore. Similarly, McDonald's management practices are adapted to across cultures. It can obviously be proved that culture should be considered in the cross-cultural business. Despite the growing awareness that cultural issues are significant when designing business management and strategies for employees from different countries, it is not difficult to find articles that purport to focus upon comparative differences between cultural groups but instead concentrate upon internal marketing (e.g., Sparrow \& Wu, 1998). The 
following discussion will outline some evidence of the cultural research as they have addressed these issues.

Early research was based on the idea that the qualities of an effective manager in the USA will translate into other cultures (Newman \& Nollen, 1996). However, there is no one best way to manage a business. This simple idea is surprisingly difficult to accept as some theoretically based propositions put forward the different arguments. Newman and Nollen (1996) have argued that management practices should be adapted to the local culture to be the most effective, supported by Hofstede's theory. According to Schuler and Rogovsky's article (1998), HR programs and international models have addressed to be built across cultures that would bundle several different HR practices and then are more closely aligned with the dimensions of their cultures. Sparrow and $\mathrm{Wu}$ (1998) have stated HR programs, and practice in Taiwan should be different from the West. They also pointed out a significant result that the increasing number of young employees in Taiwanese and Chinese organizations has rejected loyalty and tenurebased resources systems.

\section{METHODOLOGY}

Based on culture, this research tested Taiwanese and Chinese regarding similar cultural backgrounds. Firstly, this study is expected to discuss the differences between the internal marketing requirements of hotel staffs in Taiwan and mainland China. Moreover, this research divided different groups (i.e., gender, age, and length of working experience) to explore what demands employee expects and requires. This study thus is conducted by referring to the principles of Daniel (1962) to extract key factors and using the grey relative analysis (GRA) method as a classification, rating, and decision-making technique to determine the significant factors among those required for a system with a limited amount of data set. There are three types of information points involving: white, grey, or black. The main purpose is that black points have to be transferred in the system to the grey points.

This research applies GRA method consisting of six basic steps to the evaluation of a series of employee satisfaction about internal marketing practice. The evaluation criteria, weighted values, and linguistic variables need to be identified prior to the evaluation. In the research, first of all, performance criteria have been determined by experts. The goal of this evaluation is to find the factors that can adequately satisfy the series internal marketing program in multiple attributes, decision-making, and prioritize the multi-cultural background employee demands.

\section{Sample Design and Collection}

This research has targeted hotel employees in Taichung, Taiwan, and Guangzhou, 
China. According to the information from Tourism Bureau Taiwan (2017), Taichung has the second largest number of hotel staff in Taiwan, ranking only second to Taipei. Also, Guangzhou is a city that Taiwan businessman has entered earlier. The kinds of participants can decrease bias as two cities have similar cultures and life behaviors. There are 1500 questionnaires handed out from November 2015 to March 2016, and 320 and 252 valid questionnaires were received in Taiwan and mainland China respectively (see Table 1). The questionnaire includes three variables: internal marketing (IM), which has dimensions of internal communication (IC), training (T), and internal market research (IMR), culture issue (CI), and employee satisfaction (ES). The scale of items refers to a study conducted by Huang and Rundle-Thiele (2014) to ensure the reliability of measures.

Table 1. Respondent Characteristics for the Hotel Employee Sample

\begin{tabular}{|c|c|c|c|}
\hline Items & & $\begin{array}{c}\text { Taiwanese } \\
(\mathrm{n}=320)(\%)\end{array}$ & $\begin{array}{l}\text { Mainland Chinese } \\
\qquad(\mathrm{n}=252)(\%)\end{array}$ \\
\hline \multirow{2}{*}{ Gender } & Male & 32.0 & 25.8 \\
\hline & Female & 68.0 & 74.2 \\
\hline \multirow{2}{*}{ Marital status } & Married & 31.5 & 41.0 \\
\hline & Not Married & 68.5 & 59.0 \\
\hline \multirow{5}{*}{ Age } & $20 \&$ below & 1.3 & 6.4 \\
\hline & $21-30$ & 50.8 & 28.2 \\
\hline & $31-40$ & 28.6 & 25.9 \\
\hline & $41-50$ & 14.3 & 18.6 \\
\hline & $51 \&$ over & 5.0 & 20.9 \\
\hline \multirow{4}{*}{$\begin{array}{l}\text { Level of } \\
\text { education }\end{array}$} & Primary school & 0.4 & 1.4 \\
\hline & High school & 2.5 & 59.1 \\
\hline & Bachelor degree & 89.5 & 27.7 \\
\hline & Post-graduate degree & 7.6 & 11.8 \\
\hline \multirow{6}{*}{ Department type } & Customer service* & 76.1 & 57.3 \\
\hline & Administration & 4.6 & 12.3 \\
\hline & Kitchen & 1.7 & 11.8 \\
\hline & Marketing & 2.1 & 7.3 \\
\hline & Sales & 8.4 & 6.8 \\
\hline & Others & 7.1 & 4.8 \\
\hline \multirow{3}{*}{$\begin{array}{l}\text { Working } \\
\text { experience }\end{array}$} & Less 1 year & 35.7 & 41.1 \\
\hline & $1 \sim 5$ years & 43.2 & 32.5 \\
\hline & More five years & 21.1 & 26.4 \\
\hline
\end{tabular}

Notes: 1. total sample number is 572 .

$2 .{ }^{*}$ customer service as the front-line sector. 


\section{RESULTS}

The first part, respondents are divided by gender to analyze their degree of recognition about internal marketing as different gender has different requirements. The data is reported in Table 1 and Table 2.

Table 2. Numerical Value of Internal Marketing in Hotels between Taiwan and Mainland China (Divided by Gender)

\begin{tabular}{|c|l|c|c|c|c|}
\hline \multirow{2}{*}{} & \multirow{2}{*}{ Items } & \multicolumn{2}{c|}{ Taiwan } & \multicolumn{2}{c|}{ Mainland China } \\
\cline { 3 - 6 } & & female & male & female & male \\
\hline IC1 & Internal brand image & $0.683^{*}$ & $0.685^{*}$ & $0.774^{*}$ & $0.717^{*}$ \\
\hline IC2 & Internal communication program & $0.637^{*}$ & 0.595 & 0.678 & 0.600 \\
\hline IC3 & Communication materials & 0.599 & 0.585 & 0.704 & 0.586 \\
\hline IC4 & Understand organisation & $0.642^{*}$ & 0.591 & 0.679 & 0.643 \\
\hline IC5 & Appropriate communications & 0.596 & 0.584 & 0.629 & 0.558 \\
\hline IC6 & Business wide communication & 0.611 & 0.583 & 0.661 & 0.558 \\
\hline T1 & Efforts on training & $0.632^{*}$ & $0.611 *$ & 0.720 & $0.674 *$ \\
\hline T2 & Orientation program & 0.602 & 0.549 & $0.788^{*}$ & 0.552 \\
\hline T3 & Do job well & 0.609 & 0.580 & 0.659 & 0.606 \\
\hline T4 & Reason for working & $0.638^{*}$ & 0.590 & 0.666 & 0.593 \\
\hline T5 & Skill and knowledge development & 0.621 & 0.605 & 0.647 & 0.618 \\
\hline T6 & Support skills & 0.603 & $0.612^{*}$ & 0.726 & 0.594 \\
\hline IMR1 & Gather employee feedback. & 0.607 & $0.641 *$ & 0.635 & 0.608 \\
\hline IMR2 & Seek employee suggestions. & 0.576 & 0.575 & 0.689 & 0.596 \\
\hline IMR3 & Collect employee complaints. & 0.573 & 0.563 & 0.655 & 0.568 \\
\hline IMR4 & Internal market research & 0.538 & 0.546 & 0.651 & 0.631 \\
\hline IMR5 & Identify employee's issues & 0.587 & 0.583 & 0.618 & $0.673 *$ \\
\hline IMR6 & Regular surveys & 0.529 & 0.579 & $0.743^{*}$ & 0.624 \\
\hline
\end{tabular}

Note: * means key factor. 
Table 3. Numerical Value of Other Factors in Hotels between Taiwan and Mainland China (Divided by Gender)

\begin{tabular}{|l|l|c|c|c|c|}
\hline \multirow{2}{*}{} & \multicolumn{1}{|c|}{ Items } & \multicolumn{2}{c|}{ Taiwan } & \multicolumn{2}{c|}{ Mainland China } \\
\cline { 3 - 6 } & \multicolumn{1}{|c|}{ female } & male & female & male \\
\hline CI1 & Similar racial groups & 0.597 & 0.605 & $0.614^{*}$ & 0.611 \\
\hline CI2 & Different racial groups & 0.497 & 0.516 & 0.521 & 0.600 \\
\hline CI3 & Same racial group & 0.575 & 0.577 & $0.607^{*}$ & 0.553 \\
\hline CI4 & The similar way & 0.569 & 0.595 & 0.562 & 0.567 \\
\hline CI5 & Prefer to work with t the same racial group & $0.653^{*}$ & $0.665^{*}$ & $0.628^{*}$ & 0.596 \\
\hline CI6 & $\begin{array}{l}\text { Get along well with the same racial } \\
\text { background }\end{array}$ & $0.688^{*}$ & 0.579 & 0.583 & $0.629 *$ \\
\hline CI7 & $\begin{array}{l}\text { The same racial background, I work more } \\
\text { efficiently. }\end{array}$ & $0.623^{*}$ & $0.636^{*}$ & $0.602^{*}$ & $0.624^{*}$ \\
\hline CI8 & $\begin{array}{l}\text { Have poor relationships with different } \\
\text { racial background }\end{array}$ & $0.617^{*}$ & $0.629^{*}$ & 0.506 & 0.473 \\
\hline ES1 & Enough freedom & $0.621^{*}$ & $0.679^{*}$ & 0.574 & 0.601 \\
\hline ES2 & The variety of activities & 0.603 & 0.597 & 0.551 & $0.664^{*}$ \\
\hline ES3 & The opportunities & $0.631^{*}$ & 0.596 & $0.656^{*}$ & $0.709^{*}$ \\
\hline ES4 & Be satisfied with job & 0.597 & 0.579 & 0.585 & $0.628^{*}$ \\
\hline ES5 & Not consider leaving the current job & 0.591 & 0.567 & 0.542 & 0.559 \\
\hline ES6 & Do not enjoy job & 0.564 & 0.587 & 0.532 & 0.593 \\
\hline
\end{tabular}

Note: * means key factor.

According to the interaction between variables of internal marketing, culture issue and employee satisfaction and sequence of key factors shown in Table 1 and Table 2, this research concluded that females in both countries are more likely to improve work efficiency if supervisors have the same racial background with them, while males focus more on whether there is enough freedom for them to bring talents into full play. Staffs in Taiwan and mainland China both desire to get enough training programs. By contrast, gender does not cause any difference in internal communication requirements, especially the organizational branding goal. In general speaking, staffs in two shores expect an organization to satisfy all their demands about internal communication (IC) and training $(\mathrm{T})$. In particular, the organization gives to help employees have a deeper 
understanding of corporate culture and development direction and then encourages them to work. In terms of cultural issues, staffs in both countries tend to build good relationships with supervisors who have the same racial background. Compared with staff in mainland China, however, employees in Taiwan have poor relationships with supervisors from different racial groups. To sum up, there are little differences between the requirements of internal marketing on two shores caused by gender.

In the next section, this research discusses whether there are differences in demands based on age through analyzing data shown in the tables below.

\section{Table 4. Numerical Value of Internal Marketing in Hotels Between Taiwan and} Mainland China (Divided by Age)

\begin{tabular}{|c|c|c|c|c|c|}
\hline & \multirow{2}{*}{ Items } & \multicolumn{2}{|c|}{ Taiwan } & \multicolumn{2}{|c|}{ Mainland China } \\
\hline & & $\begin{array}{c}<30 \\
\text { years old }\end{array}$ & $\begin{array}{c}\geq 30 \\
\text { years old }\end{array}$ & $\begin{array}{c}<30 \\
\text { years old }\end{array}$ & $\begin{array}{c}\geq 30 \\
\text { years old }\end{array}$ \\
\hline IC 1 & Internal brand image & $0.677^{*}$ & $0.692 *$ & $0.774 *$ & 0.619 \\
\hline IC2 & Internal communication program & 0.615 & $0.617^{*}$ & 0.672 & 0.581 \\
\hline IC3 & Communication materials & 0.600 & 0.584 & 0.646 & 0.644 \\
\hline IC4 & Understand organisation & $0.632 *$ & 0.599 & $0.696^{*}$ & $0.679 *$ \\
\hline IC5 & Appropriate communications & 0.608 & 0.570 & 0.582 & 0.599 \\
\hline IC6 & Business wide communication & 0.619 & 0.573 & 0.611 & 0.603 \\
\hline $\mathrm{T} 1$ & Efforts on training & 0.622 & $0.621 *$ & $0.703 *$ & 0.633 \\
\hline $\mathrm{T} 2$ & Orientation program & 0.582 & 0.569 & 0.740 & 0.563 \\
\hline $\mathrm{T} 3$ & Do job well & 0.617 & 0.569 & 0.627 & $0.679 *$ \\
\hline $\mathrm{T} 4$ & Reason for working & $0.630^{*}$ & 0.596 & $0.556^{*}$ & 0.633 \\
\hline T5 & Skill and knowledge development & 0.617 & 0.609 & 0.624 & 0.675 \\
\hline T6 & Support skills & 0.594 & $0.623 *$ & 0.653 & 0.663 \\
\hline IMR1 & Gather employee feedback. & 0.603 & $0.646^{*}$ & 0.599 & 0.596 \\
\hline IMR2 & Seek employee suggestions. & 0.570 & 0.581 & 0.644 & 0.674 \\
\hline IMR3 & Collect employee complaints. & 0.561 & 0.575 & 0.620 & 0.671 \\
\hline IMR4 & Internal market research & 0.542 & 0.542 & 0.621 & $0.682 *$ \\
\hline IMR5 & Identify employee's issues & 0.593 & 0.576 & 0.644 & $0.771 *$ \\
\hline IMR6 & Regular surveys & 0.550 & 0.559 & 0.667 & $0.737^{*}$ \\
\hline
\end{tabular}

Note: * means key factor. 
Table 5. Numerical Value of Other Factors in Hotels Between Taiwan and Mainland China (Divided by Age)

\begin{tabular}{|c|c|c|c|c|c|}
\hline & \multirow{2}{*}{ Items } & \multicolumn{2}{|c|}{ Taiwan } & \multicolumn{2}{|c|}{ Mainland China } \\
\hline & & $\begin{array}{c}<30 \\
\text { years old }\end{array}$ & $\begin{array}{c}\geq 30 \\
\text { years old }\end{array}$ & $\begin{array}{c}<30 \\
\text { years old }\end{array}$ & $\begin{array}{c}\geq 30 \\
\text { years old }\end{array}$ \\
\hline CI1 & Similar racial groups & 0.596 & 0.607 & 0.611 & 0.576 \\
\hline CI2 & Different racial groups & 0.490 & 0.526 & 0.579 & $0.746^{*}$ \\
\hline $\mathrm{CI} 3$ & Same racial group & 0.592 & 0.558 & 0.575 & 0.558 \\
\hline CI4 & The similar way & 0.585 & 0.578 & 0.556 & 0.552 \\
\hline CI5 & $\begin{array}{l}\text { Prefer to work with } t \text { the same racial } \\
\text { group }\end{array}$ & $0.653 *$ & $0.662 *$ & $0.633^{*}$ & 0.589 \\
\hline CI6 & $\begin{array}{l}\text { Get along well with the same racial } \\
\text { background }\end{array}$ & $0.675^{*}$ & $0.648^{*}$ & 0.610 & 0.530 \\
\hline $\mathrm{CI} 7$ & $\begin{array}{l}\text { The same racial background, I work } \\
\text { more efficiently. }\end{array}$ & $0.664 *$ & $0.649 *$ & 0.613 & 0.559 \\
\hline CI8 & $\begin{array}{l}\text { Have poor relationships with different } \\
\text { racial background }\end{array}$ & 0.600 & $0.649 *$ & 0.480 & 0.550 \\
\hline ES1 & Enough freedom & $0.650 *$ & $0.650 *$ & 0.576 & 0.519 \\
\hline ES2 & The variety of activities & 0.621 & 0.576 & $0.670^{*}$ & 0.489 \\
\hline ES3 & The opportunities & $0.649 *$ & 0.575 & $0.699 *$ & $0.617^{*}$ \\
\hline ES4 & Be satisfied with job & 0.616 & 0.557 & 0.609 & 0.575 \\
\hline ES5 & Not consider leaving the current job & 0.612 & 0.541 & 0.553 & 0.508 \\
\hline ES6 & Do not enjoy job & 0.567 & 0.585 & 0.587 & $0.740 *$ \\
\hline
\end{tabular}

Note: * means key factor.

According to the interaction between variables of internal marketing, cultural issue and employee satisfaction, and sequence of key factors shown in Table 3 and Table 4, the findings have shown that based on the seniority, staffs under 30 years old require organizations to give a clear organizational branding to them. Staffs over 30 years old care more about organizations acquire their demands through internal market research, whereas those under 30 years old concern more about the freedom to complete their work. All of the staff prefer supervisors who have the same racial background as them. Compared with staff younger than 30 years old, older groups worry about having poor relationships with supervisors who come from different racial groups. Finally, the 
finding indicated that cultural issues have more influence on Taiwanese's work performance.

The third part of the results in this research explored whether seniority has influenced the requirements of the internal marketing program and then affected the satisfaction of the staff who have worked for the same length of time.

Table 6. Numerical Value of Internal Marketing in Hotels between Taiwan and Mainland China (Divided by Length of Service)

\begin{tabular}{|c|l|c|c|c|c|}
\hline \multirow{2}{*}{} & \multicolumn{2}{|c|}{ Items } & \multicolumn{2}{c|}{ Taiwan } & \multicolumn{2}{c|}{ Mainland China } \\
\cline { 3 - 6 } & & $\begin{array}{c}<\mathbf{5} \\
\text { years }\end{array}$ & $\begin{array}{c}\mathbf{2 5} \\
\text { years }\end{array}$ & $\begin{array}{c}<\mathbf{5} \\
\text { years }\end{array}$ & $\begin{array}{c}\geq \mathbf{5} \\
\text { years }\end{array}$ \\
\hline IC1 & Internal brand image & $0.683^{*}$ & $0.704^{*}$ & $0.792^{*}$ & 0.614 \\
\hline IC2 & Internal communication program & 0.616 & 0.610 & $0.685^{*}$ & 0.531 \\
\hline IC3 & Communication materials & 0.606 & 0.570 & 0.655 & 0.624 \\
\hline IC4 & Understand organisation & $0.623^{*}$ & 0.594 & $0.699^{*}$ & $0.665^{*}$ \\
\hline IC5 & Appropriate communications & 0.605 & 0.579 & 0.585 & 0.579 \\
\hline IC6 & Business wide communication & 0.617 & 0.574 & 0.613 & 0.603 \\
\hline T1 & Efforts on training & $0.625^{*}$ & 0.620 & $0.701^{*}$ & $0.666^{*}$ \\
\hline T2 & Orientation program & 0.586 & 0.565 & $0.746^{*}$ & 0.601 \\
\hline T3 & Do job well & $0.625^{*}$ & 0.555 & 0.640 & 0.588 \\
\hline T4 & Reason for working & $0.626^{*}$ & 0.588 & 0.621 & $0.699^{*}$ \\
\hline T5 & Skill and knowledge development & 0.619 & 0.627 & 0.637 & 0.591 \\
\hline T6 & Support skills & 0.602 & $0.647^{*}$ & 0.662 & 0.601 \\
\hline IMR1 & Gather employee feedback. & 0.615 & $0.648^{*}$ & 0.625 & 0.513 \\
\hline IMR2 & Seek employee suggestions. & 0.582 & 0.570 & 0.665 & 0.575 \\
\hline IMR3 & Collect employee complaints. & 0.577 & 0.539 & 0.632 & 0.639 \\
\hline IMR4 & Internal market research & 0.563 & 0.510 & 0.641 & 0.576 \\
\hline IMR5 & Identify employee's issues & 0.600 & 0.581 & 0.661 & $0.664^{*}$ \\
\hline IMR6 & Regular surveys & 0.581 & 0.540 & $0.694^{*}$ & 0.578 \\
\hline Note* & Seans key factor & & & & \\
\hline
\end{tabular}

Note: * means key factor. 
Table 7. The Numerical Value of Other Factors in Hotels between Taiwan and Mainland China (divided by Length of Service)

\begin{tabular}{|c|c|c|c|c|c|}
\hline & \multirow{2}{*}{ Items } & \multicolumn{2}{|c|}{ Taiwan } & \multicolumn{2}{|c|}{ Mainland China } \\
\hline & & $\begin{array}{c}<5 \\
\text { years }\end{array}$ & $\begin{array}{c}\geq 5 \\
\text { years }\end{array}$ & $\begin{array}{c}<5 \\
\text { years }\end{array}$ & $\begin{array}{c}\geq 5 \\
\text { years }\end{array}$ \\
\hline CI1 & Similar racial groups & 0.615 & $0.590 *$ & 0.605 & 0.646 \\
\hline $\mathrm{CI} 2$ & Different racial groups & 0.486 & 0.521 & 0.567 & 0.485 \\
\hline $\mathrm{CI} 3$ & Same racial group & 0.605 & 0.543 & 0.571 & $0.657 *$ \\
\hline CI4 & The similar way & 0.595 & 0.520 & 0.549 & 0.630 \\
\hline CI5 & $\begin{array}{l}\text { Prefer to work with } t \text { the same racial } \\
\text { group }\end{array}$ & $0.659 *$ & $0.649 *$ & $0.637 *$ & 0.625 \\
\hline CI6 & $\begin{array}{l}\text { Get along well with the same racial } \\
\text { background }\end{array}$ & $0.678^{*}$ & 0.562 & 0.607 & 0.632 \\
\hline $\mathrm{CI} 7$ & $\begin{array}{l}\text { The same racial background, I work more } \\
\text { efficiently. }\end{array}$ & $0.661 *$ & 0.570 & 0.609 & $0.677 *$ \\
\hline CI8 & $\begin{array}{l}\text { Have poor relationships with different } \\
\text { racial background }\end{array}$ & 0.634 & 0.573 & 0.477 & 0.584 \\
\hline ES1 & Enough freedom & 0.637 & $0.701 *$ & 0.577 & 0.614 \\
\hline ES2 & The variety of activities & 0.615 & 0.580 & $0.644^{*}$ & 0.575 \\
\hline ES3 & The opportunities & 0.643 & 0.561 & $0.681 *$ & $0.655^{*}$ \\
\hline ES4 & Be satisfied with job & 0.623 & 0.546 & 0.600 & 0.638 \\
\hline ES5 & Not consider leaving the current job & 0.613 & 0.546 & 0.535 & 0.562 \\
\hline ES6 & Do not enjoy job & 0.564 & 0.578 & 0.544 & 0.642 \\
\hline
\end{tabular}

Note: * means key factor.

The findings are indicated that based on the interaction between variables of internal marketing, cultural issues and employee satisfaction, and the sequence of key factors shown in Table 5 and Table 6. Staffs in both countries concern internal communication. Less experienced employees expect more training for skill improvement, while those have more experience desire that organizations can acquire and satisfy their demand through internal market research. Staffs in two shores with less than five years of working experience have the same needs of the internal marketing program, although there are some differences in the sequence of requirements. Most employees in two shores expect more assistance in training and organizational brand 
image. Employees have clearer requirements for the internal marketing program due to their more working experience. Cultural issues have more influenced on Taiwanese with less experience; however, in mainland China employees with more working experience are influenced by culture much profoundly.

At last, this study analyses whether Chinese culture in different regions will result in different employee requirements and satisfaction. The sequence of key factors is also shown in Table 7 and Table 8. According to the interaction between internal marketing, culture issues, and employee satisfaction, for instance, organizations do great internal market research to be related to higher employee satisfaction. This research finds that the hotel staffs of Taiwan and mainland China both need organizations to offer a clear brand image and training program and prefer to working with supervisors who have the same racial group. Besides, Taiwanese employees consider enough freedom to achieve work, and further improve their satisfaction, while those in mainland China expect a variety of activities and tasks to improve their satisfaction. Finally, Taiwanese more concern culture issues will influence their jobs rather than Chinese.

Table 8: Numerical Value of Internal Marketing in Hotels between Taiwan and Mainland China

\begin{tabular}{|c|l|l|l|l|}
\hline & \multicolumn{1}{|c|}{ Items } & Taiwan & $\begin{array}{c}\text { Mainland } \\
\text { China }\end{array}$ & $\begin{array}{c}\text { Taiwan } \\
\text { and } \\
\text { Mainland }\end{array}$ \\
\hline IC1 & Internal brand image & $0.683^{*}$ & $0.771^{*}$ & $0.738^{*}$ \\
\hline IC2 & Internal communication program & 0.615 & 0.675 & $0.664^{*}$ \\
\hline IC3 & Communication materials & 0.591 & 0.650 & 0.640 \\
\hline IC4 & Understand organisation & 0.616 & $0.694^{*}$ & $0.671^{*}$ \\
\hline IC5 & Appropriate communications & 0.590 & 0.596 & 0.592 \\
\hline IC6 & Business wide communication & 0.596 & 0.613 & 0.629 \\
\hline T1 & Efforts on training & $0.621^{*}$ & $0.699^{*}$ & $0.676^{*}$ \\
\hline T2 & Orientation program & 0.575 & $0.741^{*}$ & 0.649 \\
\hline T3 & Do job well & 0.594 & 0.634 & 0.636 \\
\hline T4 & Reason for working & 0.613 & 0.632 & 0.646 \\
\hline T5 & Skill and knowledge development & 0.612 & 0.633 & 0.645 \\
\hline T6 & Support skills & 0.607 & 0.665 & 0.655 \\
\hline IMR1 & Gather employee feedback. & $0.623^{*}$ & 0.622 & 0.6464 \\
\hline IMR2 & Seek employee suggestions. & 0.575 & 0.672 & 0.618 \\
\hline IMR3 & Collect employee complaints. & 0.567 & 0.641 & 0.600 \\
\hline IMR4 & Internal market research & 0.542 & 0.641 & 0.586 \\
\hline IMR5 & Identify employee's issues & 0.584 & 0.672 & 0.623 \\
\hline IMR6 & Regular surveys & 0.554 & $0.688^{*}$ & 0.613 \\
\hline No: & Ins key factor. & & \\
\hline
\end{tabular}

Note: * means key factor. 
Table 9: Numerical Value of Other Factors in Hotels between Taiwan and Mainland China

\begin{tabular}{|c|c|c|c|c|}
\hline & Items & Taiwan & $\begin{array}{c}\text { Mainland } \\
\text { China }\end{array}$ & $\begin{array}{l}\text { Taiwan } \\
\text { and } \\
\text { Mainland }\end{array}$ \\
\hline CI1 & Similar racial groups & 0.601 & 0.612 & 0.606 \\
\hline $\mathrm{CI} 2$ & Different racial groups & 0.506 & 0.557 & 0.528 \\
\hline $\mathrm{CI} 3$ & Same racial group & 0.576 & 0.582 & 0.578 \\
\hline CI4 & The similar way & 0.582 & 0.563 & 0.574 \\
\hline CI5 & $\begin{array}{l}\text { Prefer to work with } t \text { the same racial } \\
\text { group }\end{array}$ & $0.686^{*}$ & $0.642 *$ & $0.666^{*}$ \\
\hline CI6 & $\begin{array}{l}\text { Get along well with the same racial } \\
\text { background }\end{array}$ & $0.662 *$ & 0.604 & $0.661^{*}$ \\
\hline $\mathrm{CI} 7$ & $\begin{array}{l}\text { The same racial background, I work more } \\
\text { efficiently. }\end{array}$ & $0.656^{*}$ & 0.612 & $0.661^{*}$ \\
\hline CI8 & $\begin{array}{l}\text { Have poor relationships with different } \\
\text { racial background }\end{array}$ & 0.623 & 0.490 & 0.564 \\
\hline ES1 & Enough freedom & $0.649 *$ & 0.586 & 0.648 \\
\hline ES2 & The variety of activities & 0.599 & $0.647 *$ & 0.643 \\
\hline ES3 & The opportunities & 0.613 & $0.680^{*}$ & $0.665^{*}$ \\
\hline ES4 & Be satisfied with job & 0.588 & 0.604 & 0.621 \\
\hline ES5 & Not consider leaving the current job & 0.578 & 0.549 & 0.565 \\
\hline ES6 & Do not enjoy job & 0.575 & 0.559 & 0.568 \\
\hline
\end{tabular}

Note: * means key factor.

\section{Conclusion}

The study indicated that employees in Taiwan and mainland China have similar requirements of internal marketing regarding personal demographics (i.e., gender, age, and length of working experience), although they are under different growing background and environment. There are several conclusions drawn below: first, staffs must know more about brand images and development directions of organizations regardless of age and gender. Second, the older and senior staffs expect that the organization has regular internal marketing researches to explore and understand their needs and thus to improve employee satisfaction. Third, the younger and less 
experienced staffs are more concerned about the training programs, which improve their skills, promote career development, and thus improve employee satisfaction. Fourth, staffs in two shores prefer to working with supervisors from the same racial group due to improve job efficiency. The finding also shows that cultural issues have more influenced on the work performance of Taiwanese. At last, cultural issues have different influences on staff on two shores in terms of length of working experience.

The findings also have implications for the managers who face internal marketing problems in the services organization, especially for hotels. Perhaps most apparent is the suggestion that workers with more working experience will find the most significant level of demands of internal market research when placed in high-customer-contact positions. When workers are placed in low-level sensitivities, the organization should satisfy their needs for training for delivering service. Of general concern, perhaps, is the placement of a worker whatever lives in Taiwan and/or Mainland China both concern great internal marketing practice. Managers practicing internal marketing will play an important role in combining and integrating different perspectives. If academics and managers are to use internal marketing as a means to enhance organizational effectiveness and functions, they must, themselves, firstly build a deeper understanding of internal marketing. In recent years, finally, more circulation of talent requires adjusting human resource strategy based on talent requirements in Taiwan and mainland China, especially the differences caused by age and length of service. Additionally, employees in two shores with different levels of sensitivity have different cultural issues. Therefore, work performance can be improved if the department of human resources is concerned about these differences, and also decrease employee turnover and recruit talented employees, and ultimately increase satisfaction.

The GRA results demonstrate the positive contribution that both countries employees' need about the internal marketing program, which enhances the ability to identifying efficiency and notably increases in the relation and relative importance in any processes and supports of HRM. Firstly, this study indicated the internal marketing practice, incorporating three dimensions and 18 sub-dimensions to represent internal marketing characteristics. The criteria included in this paper, however, can be selectively used or aggregated according to the judgment of the lodging industry in Greater China. It will be more flexible as managers in practice can get an insight to identify as well as evaluate failure approaches. It is also expected to be a guideline for managing the internal marketing program in the practice of Greater China. Secondly, the GRA applied to the relationship between internal marketing and employee satisfaction comparing two countries in Greater China established in this research is actually quite valuable in practice. Finally, from the methodological perspective, this paper contributes to the field in that it used GRA, addressing the limitations of previous 
calculations of risk priority, which are too simple to apply in a practical setting.

In assessing internal marketing in the current study, the measure asked employees to provide perceptual responses; that is, respondents indicated their level of satisfaction with internal marketing practice regarding their hotels' internal marketing systems. No effort was made to identify concrete things that internal marketing practice did that caused employees to feel the way HR managers did. Therefore, it would be good to conduct additional research to try to establish the specific actions in which hotel management engages, and the specific cultural background (i.e., different countries in Greater China) have in place that influence employees' perceptions of internal marketing efforts. The results could help hotel management to understand better the workings of internal marketing in the Greater China lodging sector. Besides, because a definitive determinant of the internal marketing program is the employees, the future headings for this exploration likewise include the target and subjective perspectives of the site from the employees' point of view.

\section{REFERENCE}

Ballantyne, D. (2000). The strengths and weaknesses of internal marketing. In Varey, R.J. \& Lewis, B.R. (Eds.). Internal marketing: Directions for management (pp.43-60). Routledge, London. https://doi.org/10.4324/9780203207352.ch3

Barros, C. P. (2004). A stochastic cost frontier in the portuguese hotel industry. Tourism Economics, 10(2), 177-192. https://doi.org/10.5367/000000004323142416

Bearden, W. O., \& Netemeyer, R. G. (1999). Handbook of marketing scales: Multi-item measures for marketing and consumer behavior research (2nd ed.). California: SAGE Publications, Inc.

Berry, L. L., Hensel, J. S., \& Burke, M. C. (1976). Improving retailer capability for rffective consumerism response. Journal of Retailing, 52(3), 3-14.

Bowers, M. R., \& Martin, C. L. (2007). Trading places redux: Employees as customers, customers as employees. Journal of Services Marketing, 21(2), 88-98. https://doi.org/10.1108/08876040710737859

Bruhn, M., \& Georgi, D. (2000). Information-based analysis of service quality gapsmanaging service quality by internal marketing. Journal of Professional Services Marketing, 21(2), 105-124. https://doi.org/10.1300/j090v21n02_08

Chang, C. S., \& Chang, H. C. (2008). Perceptions of internal marketing. Journal of Advanced Nursing, 65(1), 92-100. https://doi.org/10.1111/j.1365-2648.2008.04844.x

Flipo, J. P. (1986). Service firms: Interdependence of external and internal marketing strategies. European journal of Marketing, 20(8), 5-14. https://doi.org/10.1108/eum0000000004658 
George, W. R., \& Gronroos, C. (1989). Developing customer-conscious employees at every level-Internal marketing. New York: AMACOM.

Göunaris, S. (2008). The notion of internal market orientation and employee job satisfaction: Some preliminary evidence. Journal of Services Marketing, 22(1), 68-90. https://doi.org/10.1108/08876040810851978

Gronroos, C. (1978). A service-orientated approach to marketing of services. European Journal of Marketing, 12(8), 588-601. https://doi.org/10.1108/eum0000000004985

Gronroos, C. (2000), Service management and marketing: A customer relationship management approach (2nd ed.). Wiley, Chichester.

Huang, Y. S., \& Chi, T. C. (2004). Internal marketing, organizational culture, job satisfaction, and operational performance: A study on international-class tourist hotels in Taiwan. Journal of Management System, 11, 485-507.

Huang, Y. T., \& Rundle-Thiele, S. (2014). The moderating effect of cultural congruence on the internal marketing practice and employee satisfaction relationship: An empirical examination of Australian and Taiwanese born tourism employees. Tourism Management, 42, 196-206. https://doi.org/10.1016/j.tourman.2013.12.005

Huang, Y.-T. (2019). Internal marketing and internal customer: A review, reconceptualization, and extension. Journal of Relationship Marketing, https://doi.org/10.1080/15332667.2019.1664873

Huang, Y.-T., \& Rundle-Thiele, S.R. (2015). A holistic management tool for measuring internal marketing activities. Journal of Services Marketing, 29(6/7), 571-584. https://doi.org/10.1108/jsm-03-2015-0112

Huang, Y.-T., Rundle-Thiele, S. R., \& King, C. (2010). Internal marketing: A literature review and research agenda. Paper presented at the The Academy of Marketing Conference.

Huang, Y.-T., Rundle-Thiele, S.R., \& Chen, Y.-H. (2018). Extending understanding of the internal marketing practice and employee satisfaction relationship: A budget Chinese airline empirical examination. Journal of Vacation Marketing, 25(1), 8898. https://doi.org/10.1177/1356766718757270

Hwang, S. N., \& Chang, T. Y. (2003). Using data envelopment analysis to measure hotel managerial efficiency change in Taiwan. Tourism management, 24(4), 357-369. https://doi.org/10.1016/s0261-5177(02)00112-7

Joseph, W. B. (1996). Internal marketing builds service quality. Journal of Health Care Marketing, 16(1), 54-59.

Joung, H. W., Goh, B. K., Huffman, L., Yuan, J. J., \& Surles, J. (2015). Investigating relationships between internal marketing practices and employee organizational 
commitment in the foodservice industry. International Journal of Contemporary Hospitality Management, 27(7), 1618-1640. https://doi.org/10.1108/ijchm-052014-0269

Kale, S. H. (2007). Internal marketing: an Antidote for Macau's labour shortage. Gamimg Research \& Review Journal, 11(1), 1-11.

Kim, J. S., Song, H. J., \& Lee, C. K. (2016). Effects of corporate social responsibility and internal marketing on organizational commitment and turnover intentions. International Journal of Hospitality Management, 55, 25-32.

https://doi.org/10.1016/j.ijhm.2016.02.007

Lassk, F. G., Norman, K., \& Goolsby, J. R. (2004). Exploring the internal customer mind-set of marketing personnel. Journal Relationship Marketing, 3(2/3), 89-106. https://doi.org/10.1300/j366v03n02_06

Lin, C. F., \& Lin, Y. Y. (2010). Internal and external marketing for exotic restaurants. Journal of Foodservice Business Research, 13(3), 193-216. https://doi.org/10.1080/15378020.2010.500243

Lo, A.S., Stalcup, L.D., \& Lee, A. (2010). Customer relationship management for hotels in Hong Kong. International Journal of Contemporary Hospitality Management, 22(2), 139-159. https://doi.org/10.1108/09596111011018151

Morgan, N. A., \& Piercy, N. F. (1992). Barriers to marketing implementation in UK professional service firms. Journal of Professional Services Marketing, 8(1), 95114. https://doi.org/10.1300/j090v08n01_08

Nart, S., Sututemiz, N., Nart, S., \& Karatepe, O. M. (2019). Internal marketing practices, genuine emotions and their effects on hotel employees' customer-oriented behaviors. Journal of Human Resources in Hospitality \& Tourism, 18(1), 47-70. https://doi.org/10.1080/15332845.2019.1526509

Newman, K. L., \& Nollen, S. D. (1996). Culture and congruence: The fit between management practices and national culture. Journal of International Business Studies, 27(4), 753-779. https://doi.org/10.1057/palgrave.jibs.8490152

Ongori, H. (2007). A review of the literature on employee turnover. African Journal of Business Management, 1(3), 49-54.

Peltier, J., Schibrowsky, J. A., Schultz, D. E., \& Zahay, D. (2006). Interactive IMC: The relational-transactional continuum and the synergistic use of customer data. Journal of Advertising Research, 46(2), 146-159. https://doi.org/10.2501/s0021849906060193

Phillips, P. A. (1999). Hotel performance and competitive advantage: A contingency approach. International Journal of Contemporary Hospitality Management, 11(7), 359-365. https://doi.org/10.1108/09596119910293268

Piercy, N. F., \& Morgan, N. (1995). Internal marketing - The missing half of the 
marketing programme. Long Range Planning, 24(2), 82-93.

https://doi.org/10.1016/0024-6301(91)90083-z

Quester, P. G., \& Kelly, A. (1999). Internal marketing practices in the Australian financial sector: An exploratory study. Journal of Applied Management Studies, $8(2), 217$.

Rafiq, M., \& Ahmed, R. K. (1993). The scope of internal marketing: Defining the boundary between marketing and human resource management. Journal of Marketing Management, 9, 219-232.

https://doi.org/10.1080/0267257x.1993.9964234

Roberts-Lombard, M. (2010). Employees as customers - An internal marketing study of the Avis car rental group in South Africa. African Journal of Business Management, 4(4), 62.

Schuler, R. S., \& Rogovsky, N. (1998). Understanding compensation practice variations across firms: The impact of national culture. Journal of International Business Studies, 29(1), 159-177. https://doi.org/10.1057/palgrave.jibs.8490030

Sparrow, P., \& Wu, P. C. (1998). Does national culture really matter? Predicting HRM preferences of Taiwanese employees. Employee Relations, 20(1), 26-56. https://doi.org/10.1108/01425459810369823

Tag-Eldeen, A., \& El-Said, O.A. (2011). Implementation of internal marketing on a sample of Egyptian five-star hotels. Anatolia, 22(2):153-167. https://doi.org/10.1080/13032917.2011.597931

Tsai, Y., \& Tang, T. W. (2008). How to improve service quality: Internal marketing as a determining factor. Total Quality Management, 19(11), 1117-1126. https://doi.org/10.1080/14783360802323479

Teague, J., \& Eilon, S. (1973). Productivity measurement: A brief survey. Applied Economics, 5(2), 133-145. https://doi.org/10.1080/00036847300000010

Tourism Bureau Taiwan (2017). Nov .2017 Monthly Report of hotel enterprises in Taiwan. http://admin.taiwan.net.tw/statistics/month_en.aspx?no=14

Tsai, Y. F., \& Wu, S. W. (2007). Use the concept of market orientation and internal marketing to improve service quality. Paper presented at the IEEE. https://doi.org/10.1109/wicom.2007.1624

Tsai, Y.-F., \& Tang, T.-W. (2008). How to improve service quality: Internal marketing as a Determining Factor. Total Quality Management, 19(11), 11. https://doi.org/10.1080/14783360802323479

Varey, R. J. (1995). Internal marketing: A review and some interdisciplinary research challenges. International Journal of Service Industry Management, 6(1), 40-63. https://doi.org/10.1108/09564239510078849

Vella, P. J., Gountas, J., \& Walker, R. (2009). Employee perspectives of service quality 
in the supermarket sector. Journal of Services Marketing, 23(6), 407-421. https://doi.org/10.1108/08876040910985870

Welch, M., \& Jackson, P.R. (2007), Rethinking internal communication: A stakeholder approach. Corporate Communications, 12(2), 177-198. https://doi.org/10.1108/13563280710744847

Wildes, V. J., \& Parks, S. C. (2005). Internal service quality: Marketing strategies can help to reduce employee turnover for food servers. International Journal of Hospitality \& Tourism Adminstration, 6(2), 1-27. https://doi.org/10.1300/j149v06n02_01

Dr. Yu-Ting Huang is an Assistant Professor for Department of Tourism at Shih Hsin University in Taiwan. She is an emerging tourism and marketing scholar who specializes in internal marketing and cross-cultural studies. Drawing on her tourism and hospitality, Yu-Ting's research insights provide practical insights for tourism managers. She has published 10 articles in international journals and 15 articles in domestic and international conferences. She was also involved in a number of industry-related projects with a specific focus on uncovering service quality and consumer satisfaction. Yu-Ting has teaching experience in Marketing, Tourism, and International Business in the Asia-Pacific universities.

Prof. Tzong-Ru Lee is a professor at the Department of Marketing, National Chung Hsing University, Taiwan. His research interests include Supply chain management and decision making, Product brand management and decision making, Internet marketing and ecommerce, Logistics decision-making, Management Science, Technology and Innovation, Corporate strategy / competitive dynamics, and cultural industry development. He currently serves as Chief-Editor of IJAITG, and serves as Associate Editor of IJLEG, IJGC, IJAQM. He has published four books and more than 100 articles in domestic and international journals.

Yi-Jyun Jiang is a student at Department of Applied Economics, National Chung Hsing University. 